\title{
THE PROBLEM OF INTERNATIONAL CARTELS AND INTERGOVERNMENTAL COMMODITY AGREEMENTS
}

\author{
KLAUS E. KNORRT
}

THE United States is engaged in a determined effort to resurrect a world trading system capable of contributing to a high and stable level of real income throughout the world. The productive powers of mankind, it is emphasized, are enormous. Yet to produce maximum benefit, these powers must be applied fully and economically. The intermittent under-employment of resources characteristic of the business cycle must be prevented as far as possible by co-ordinated policies aiming at high and stable levels of production. Economic resource utilization must be promoted by an intelligent division of labor which encourages production where it is cheapest in terms of economic effort. International trade is the basis upon which international division of labor rests.

To be sure, the United States program does not aim at a regime of free trade and laissez faire. It is realized that the freedom of action of nations is limited "by what exists and by what can be agreed upon." 1 All countries are determined to maintain or create certain important industries by interference with the free market. It is also realized that, under present conditions, the free play of market forces often produces socially undesirable results. The Bretton Woods Agreement and the United States Proposals for Expansion of World Trade and Employment contain numerous provisions for legitimate intervention in the free market. But within limits of practicability and prudence, it is suggested that the free price mechanism be given full scope to direct the flow of goods, services, and investment capital because this mechanism tends to make for optimum resource allocation and hence for maximum productivity.

The United States, therefore, proposes that the nations join in national and international efforts to release world trade from obstructions and excessive restraints. In addition to trade barriers of various kinds imposed by governments and the problem of moderating the fluctuations of the business cycle, the United States Trade Proposals single out two problem areas: (1) restrictions imposed by private business enterprises on the international flow of goods, and (2) the disorder and the fear of disorder in the markets of certain primary com-

† Research Associate, Yale Institute of International Studies; associate economist, Food Research Institute of Stanford University, 1941-5; author of Tin Under Control (1945) and World Rubber and Its Regulation (19.45).

1. Proposals For Expanston Of World Trade aid Eisploneseit, Dep't of State Publication No. 2411 (1945) 1 (hereinafter referred to as U. S. Trade Prorosals). 
modities which in the past led to restrictive expedients and contributed to the disintegration of world trade.

\section{Private International Cartels}

In its endeavor to liberate world trade from immoderate restrictions, the United States government has expressed its concern over "activities on the part of private commercial enterprises which have the effect or purpose of restraining international trade, restraining access to international markets, or of fostering monopolistic controls in international trade." 2 To dismantle or moderate trade barriers imposed by governments would indeed be illogical if private business enterprises remained free to maintain trade restrictions of their own and thereby counteract the expansive effect expected from the reduction of governmental restrictions.

Attention is focused on international cartels, i.e., arrangements between independent enterprises in two or more countries for the purpose of submitting their competitive activities to some form of common control. Eliminating or curtailing competition is a means of obtaining higher net returns to producers or sellers than would accrue in the absence of cartelization. Given a sufficient degree of monopolistic control over the industry concerned, the cartel can augment profits by manipulating prices, either directly by price-fixing or indirectly by adjusting supply to current demand. Since the unit price desired is higher than the free-market price, "adjustment" of supply to demand involves in the long run restriction of supplies. However, because the financial and managerial independence of the members is preserved and the monopoly power enjoyed is rarely perfect, international cartels do not permit the maximization of monopoly profits which, in theory, can be attained by the single monopolist.

The forms assumed and the methods employed by international cartels are varied. National and/or designated foreign markets may be assigned entirely or partially to individual members or to national cartel organizations. Effective competition is thus precluded except possibly for special areas within which freedom of action is preserved. Minimum prices or uniform sales prices may be set by the international cartel, and sometimes common selling agencies are established with orders pooled and allocated according to previously agreed formulae. Quota agreements often limit members to definite percentage shares in the total production or export volume periodically fixed by the cartel. Additions to output capacity or the introduction of new products may be limited. Occasionally, profit-sharing arrangements are undertaken. Agreements on patent licenses are frequently combined with restrictive practices because of the facility with which legal action

2. Id. at 26 . 
can be taken for infringement of patent rights, the license being terminated as soon as the other party violates other provisions of the agreement that divide markets or fix quotas. The specific method and form adopted by an international cartel depends largely upon the character of the industry and its products, the degree of monopoly power enjoyed, internal cohesion, and the attitude of the respective governments.

Not all industries are adapted to cartelization, national or international. Conditions are most suitable where the products are comparatively homogeneous and where the number of independent concerns is small. Concentration of production in relatively few enterprises is characteristic of capital-intensive industries which operate under conditions of sharply decreasing costs as the output volume increases. It is also encouraged when tied to the exploitation of rare natural resources. International cartels have been particularly frequent, therefore, in many mining and refining industries (copper, zinc, lead, aluminum, steel, petroleum, potash, etc.) and in industries manufacturing such products as chemicals and drugs, cement, linoleum, wood pulp and paper, plate glass and bottles, incandescent lamps, electrical cables, etc.

International cartels are unstable organizations often brealing down intermittently and being reformed, with changing membership and control methods. They are born and they die both during depressions and in times of prosperity. Though existing prior to World War I, they greatly increased in number and scope during the interwar period. Their creation might be simply explained on the ground that, in the pursuit of maximum profits, entrepreneurs will naturally seek to combine for the purpose of limiting free competition. That is a plausible hypothesis. Yet more specific reasons can be cited for the recent largescale emergence of cartels.

Industrial combinations of all kinds are characteristic outgrowths of the increasing tendency toward the concentration of production in large, heavily-capitalized enterprises which seldom face the smooth and fluid process of perfect competition described in economic textbooks. ${ }^{3}$ Imperfect and especially monopolistic competition are accompanied by considerable waste and risk. Confronted with shrunken demand in times of depression or with conditions of surplus output facilities ${ }^{4}$ in the industry, competitive adjustment is difficult and painful in industries with large investments in highly specific capital

3. See Canada and International Cartels (Rep. of Comm'r, Combined Investigation Act, 1945) 55-6.

4. Surplus production capacity in this sense is to be defined as facilities in excesz of reserves required in boom times. But under conditions of a markedly fluctuating busines 3 cycle, the magnitude of the reserve capacity required is, of course, reflected in a parmanent burden of high fixed costs. 
goods. The difficulty becomes extreme when demand for the product is rather inelastic to price as is true for industrial raw materials and semi-manufactures and many durable manufactured goods. Falling prices and profits do not result in curtailed production schedules or in the disinvestment of redundant capacity. Instead there is a strong tendency to struggle for survival and to continue production as long as prices cover direct costs. In other words, the equilibrating forces of the free market fail to work automatically and speedily. Such circumstances impart an inevitable desire to escape from unregulated competition through government intervention (tariffs, import quotas) or private business agreements (cartels) or both.

Viewed historically, cartelization received a strong impetus from the overexpansion of many industries during World War I and the postwar boom, the progressive concentration of industrial enterprise and financial control in the 1920's, and the severity of the Great Depression. International cartelization was greatly facilitated by the spread of national monopolistic combinations, in turn encouraged by the rapid growth of tariffs, foreign exchange control and other trade barriers and the friendly or tolerant attitude of many governments. In the early 1930's, indeed, compulsory cartelization made its appearance in Japan, Germany, Italy, and elsewhere. Government-backed schemes of regulating large sections of foreign trade by means of private business arrangements were officially discussed by France and Germany and are tellingly epitomized by the Düsseldorf Agreement of March, 1939, between the Federation of British Industries and the Reichsgruppe Industrie. ${ }^{5}$ This astonishing agreement envisaged the replacement of "destructive competition" by a comprehensive series of private business agreements between German and British groups.

The economic effects ${ }^{6}$ of international cartel practices cannot be assessed with precision; generalized conclusions must remain vague and tentative. This results not only from our lack of exact knowledge as to what would have happened, to an industry in the absence of cartelization. It also follows from the facts that different industries possess different characteristics, that international cartels pursued different methods of abating competition and that, even when the same methods are employed, they are not applied with identical rigor and thus do not produce exactly the same effects. Nevertheless deductive calculation based on economic principles and inductive reason-

5. Hexner, International Cartels (1945) 402-4.

6. Political implications and effects are disregarded in this paper. Their importance has been somewhat exaggerated of late. The United States Trade Proposals rightly base their case against international cartels on economic and commercial considerations. For a reasonable discussion of the political and security aspects of the problem see HexNen, op. cit. supra note 5, at c. 8; Mason, The Future of International Cartels (1944) 22 Foreran Affairs 604, 610-4. 
ing based on such case studies as are available justify certain inferences on the general consequences of restrictive cartel practices.

There is no doubt that cartel practices, which reduce or abolish competition, lead to monopolistic pricing and that the monopolistic price exceeds the competitive price. Higher prices mean diminished consumption, the extent of the decrease being determined by the responsiveness of demand to price changes. Increased prices are in part necessary to offset rising production costs. Most cartelized industries operate under conditions of diminishing costs and, as outputs are restricted, relatively invariable production costs rise per unit of output. The protection of inefficient producers and the preservation of surplus output capacity-both of which might eventually be eliminated in the absence of cartelization-likewise tend to raise the average cost level of the industry concerned. Furthermore, by retarding or blocking investments in new and improved productive capacity and, possibly, by discouraging technical progress, ${ }^{7}$ cartels tend to arrest or slow up a secular decline in the average cost level which, under competitive conditions, would lead to lower prices.

How high prices will be pushed in order to secure satisfactory profits depends primarily upon the extent of monopoly power possessed by the cartel, on the price elasticity of demand for the product in question, and on the quality of cartel management. An international cartel facing considerable competition by outsiders or by substitute products, or selling an article for which the demand is highly responsive to price changes, will follow a less ambitious price policy than one for which the opposite conditions prevail. Cartel management is likely to reflect the partly divergent interests of different members and, particularly, cartel policies and decisions may embody compromises between the desires of high-cost and of low-cost producers. It is wrong to assume, moreover, that cartels will automatically follow a greedy policy even if their monopolistic control is nearly complete. They may and sometimes do pursue a moderate policy..$^{3}$ However, the temptation to follow an exploitative policy is apparently hard to resist.

When suspending competition, cartel practices are also likely to have a restrictive effect on employment. To be sure, resources set free because of restricted production might be employed in the competitive section of the economy. But labor mobility is usually limited and the transfer of specific capital goods rarely practicable. In depression, moreover, the absorptive capacity of the competitive economy is very small. Most likely, there will be a net deficit on employment account.

7. It is wrong to assume, however, that cartelization precludes an incentive toward enhancing productive efficiency. No matter what the price, producers can increace their profits by minimizing costs. But under conditions of cartelization, the fruits of technical progress are far less likely to be passed on to the consumer than under free-marliset conditions.

8. HeXNer, op. cit. supra note 5, at 95. 
This tendency may be reinforced if cartels unduly limit the introduction of new techniques and products in order to protect old investments.

Cartels both national and international thus do not measure up to the first test which must be applied to all planned intervention in the world market; in the long run, they diminish rather than raise international income. Cartels have been defended on diverse grounds. It has been said that they allow economies of distribution (especially advertising), but on the whole such savings have counteracted costraising tendencies only to a small extent. It has been pointed out that cartels have been formed in response to obstinate problems, such as the existence of redundant production capacity. But there is no case on record of an international cartel removing the excessive margin. What benefit was conferred on investors was far outweighed by the injury done to consumers. Cartels have been praised as agents of stability in an unstable world. Yet rigid prices for a few selected products are scarcely of benefit when the general price level is subject to violent fluctuations. ${ }^{9}$ Most international cartels, moreover, have been unable to moderate price gyrations except over short periods because they were too unstable as organizations or because their concern over achieving satisfactorily high prices led them to adopt a policy of short supplies which could not be rapidly supplemented when demand abruptly expanded. Professor Schumpeter ingeniously concedes the restrictive effects of monopolistic enterprise, but believes that private monopolies encourage technological progress because they furnish insurance against the risks of long-range investing under competitive conditions, and that society gains more from this stimulus to investment than it loses through restrictive practices. ${ }^{20}$ However, he cites no evidence in support of this theory.

While it must be recognized that cartels are evolved in response to acute industrial problems, it need not be conceded that the remedy is socially desirable. If it benefits investors and promises security, it does so primarily at the expense of consumers and to the detriment of economic advancement. The planner of a reformed world trading system-relatively unfettered, multilateral, and expansive-must view international cartels as grave impedients. He need not single them out with the fervor of the zealot for they are only one part of the jungle of restrictive practices, private and governmental, which flourished during the 1930's. But neither must he underestimate them. International cartels restrict the flow of goods in international trade, often more drastically than governmental trade barriers. ${ }^{11}$ Often they

9. Machlup, The Nature of the International Cartel Problem in Edwards et al., A Cartel Policy for the United Nations (1945) 1, 15.

10. Schumpeter, Capitalisar, Socialism, and Democracy (1942) 84 et seq.

11. Especially when they provide for reciprocal protection of domestic markets. Whero the domestic market is fully reserved to the national member or group, the restrictive effect 
direct world trade away from the most efficient channels. Endeavoring to achieve security by restrictive means, they imporerish the world by diminishing the efficiency of resources employed in the industries concerned. Since they are commonly formed by business enterprises in industrially advanced nations, they also tend to shift the terms of trade to the detriment of less industrialized countries. ${ }^{12}$ In short, most international cartel practices conflict with measures to liberalize international trade policy.

What can be done to stop or mitigate the restrictive practices of international cartels? Or, more precisely, what program can be devised that is at once satisfactory on economic principle and politically practicable? It is within this frame of reference that an answer must be discovered. Projection of the perfect should not prejudice the achievement of the good. It is also clear that it is a workable international. solution which must be found. To be sure, unilateral action is by no means useless if adopted by commercially important countries like the United States and Great Britain. ${ }^{13}$ Individual countries, however, are affected by the practices of international cartels quite beyond their legal reach. Uncoordinated national action is not enough. What is required is an international remedy. ${ }^{14}$

The search for a suitable solution should logically start with the basic factors that stimulated the growth and spread of international cartels. Indeed, it has been claimed that a simple program of international "trust-busting" will scarcely be accepted and, if accepted, will not work unless these underlying conditions are duly taken into account. ${ }^{15}$ There is some truth and wisdom in this contention. Among the motives propelling cartelization, a distinction must be made between the desire to mulct the consumer and the more or less legitimate desire for security. As far as the latter is concerned, to deny the specific remedy of cartelization is to leave legitimate wants unsatisfied. But the campaign against international cartels is only part of an integrated program toward liberalizing and stabilizing world trade.

Provided the United States Trade Proposals are translated into practice with reasonable success, the impetus toward international

equals that of a prohibitive tariff; where it is partially reserved, the effect is identical sith that of an import-quota system.

12. Terrill, The Anterican Trade Proposals: Restrictice Busincss Pradices (1910) 14 Dep't of State Bull. 455, 457.

13. Vigorous action against national and international business agreements in the United States, the repeal of the Webb-Pomerene Act [ 10 SraT. 516 (1918), 15 U. S. C. $₹ 61$ (1910)], and strong international competition by American firms would in many fields handicap the operation of international cartels set up abroad. See Kreps, Esporience crill Urilateral Action Tourard International Carlels in EDwanos cl al., op. cit. stupra note 9, at 70, 91-3.

14. Assistant Secretary of State Clayton, Pricate Barricrs to International Trade (1945) 12 DeP'T of State Bull. 933, 935.

15. See, e.g., International Cartels (19.14) 147 THE EcoNosusr 724. 
cartelization would automatically be weakened. If government trade obstacles are substantially reduced, quota and preferential restrictions largely dismantled, and foreign exchange control normally confined to long-term capital transactions, the formation of national cartels would be rendered more difficult, and some tendencies toward the overexpansion of industries would be inhibited. ${ }^{16}$ If the major industrial nations manage to maintain employment at a high and stable level, industries would be far more likely than before to enjoy high and stable volumes of demand and relatively stable prices. It is also well to recall that some cartels were the direct legacy of World War I and that structural maladjustments arising out of the dislocations of war and its aftermath should preferably be removed by international adjustment plans that cannot be elaborated in the abstract. In a limited number of cases, overexpanded raw materials industries may be subjected to the correctives contemplated by intergovernmental commodity agreements.

But even such profound changes on the international economic scene would leave unimpaired some powerful stimuli toward cartelization, and there would still be need for specific countermeasures. Proposals have been advanced ranging from the categorical eradication of all monopolistic enterprizes to a mere insistence on increased publicity on international cartel agreements and policies. The radical demand for outlawing all monopolies, often including plans for dissolving giant corporations and the systematic deconcentration of industries, is obviously utopian and scarcely desirable. Responsible quarters consider the elimination of all cartels outside the area of practical politics, although such a sweeping step should not only seriously handicap attempts at forming international cartels but also force greatly extended competition in world trade. ${ }^{17}$ On the other hand, establishing an international fact-gathering and -disseminating agency, though quite practicable, is not enough. Such an agency should find it difficult to secure all pertinent information on cartel contracts and behavior, and what publicity it could afford would surely not safeguard the public interest against the abuse of cartel power.

Most proposals can be reduced to two types, one designed to curb the restrictive practices of international business arrangements, the other to establish public regulation of international cartel activities. ${ }^{18}$ Compulsion is inherent in both alternatives. But, though an inter-

16. Governmental protectionism is often at least a partial cause of excess output capacity."

17. See Hoover, INTernational Trade and Domestic EMployment (1945) 75-6.

18. A comprehensive cartel program "could take the form either of an international agreement to prohibit restrictive business practices in international trade or, alternatively, the establishment of a body or bodies to supervise and control in the public interest the activities of international cartels." Clayton, loc. cit. sttpra note 14. 
national solution is envisaged, there is general agreement that the nations are unwilling to confer adequate powers on an international body and that enforcement will necessarily remain with the individual states. Accordingly, the practicable approach will involve parallel international and national action. A suitable program must be accepted by an international conference, and such international institutions set up as can be agreed upon. Each participating government must then undertake to enforce the provisions of the convention within its own jurisdiction.

The proponents of public regulation of international cartels aver that cartel arrangements are here to stay and that they are indispensable for dealing with industrial maladjustments. They admit, however, that control power is subject to serious abuse if vested in the hands of private entrepreneurs. The remedy they suggest is to convert cartels into useful instruments of public policy by placing them under governmental supervision. Thus, it is urged that governments agree to compel public registration and advance clearance of all international business arrangements. National producers desiring to participate in international cartels would have to file with a government bureau information about membership and the stipulations of the agreement and secure governmental approval.

Compulsory registration affords an indispensable basis for adequate publicity which must be the first step toward preventing the imposition of private trade barriers. But it is the first step only. In other respects, this scheme seems of dubious value. What is important is not only the basic cartel agreement but also the manner in which it is applied. Officials could not appraise the effects in advance. The possibility of evasion is manifest. Formal control arrangements may be duly recorded and approved, while substantive policy may be largely determined by informal consultation. Adding an official observer to all meetings of the control management does not suggest a notable improvement. Civil servants rarely have the technical competence required for effective supervision, and governments are too often subject to pressure on the part of well-organized business groups. Mr. Clayton's diagnosis is correct. Past attempts in various countries at governmental control of business policies with respect to production and price "have revealed a strong tendency for the principles and aims of the regulated group to become those of the regulating authority." 19

That the machinery of government in most countries is ill-equipped for this task is the chief weakness of all plans for preserving international cartels under public supervision. This has prompted Sir Wrilliam Beveridge to make the curious suggestion that what is needed is "that those who have the responsibility of conducting great and highly

19. Ibid. 
organized industries should come to regard themselves as the agents of a wider policy than that of their business." ${ }^{20}$ Just how this can be achieved, he adds, "can probably be learned only by experience." 21 Yet this fond hope is doomed to frustration unless human nature is altered or the capitalistic system dissolved. The free-enterprise system must rest squarely on the profit motive. Beyond that no more can be expected from the entrepreneur than obedience to public laws. He cannot be converted into a public servant by exhortation.

Two other objections can be directed against this type of scheme. International cartels could be so regulated only under condition of de facto agreement between the main exporting countries. Such agreement might not easily be attained and, if it were, there would be considerable danger of agreement substantially at the expense of the importing countries. International friction might easily arise from such a situation. To minimize this danger, the suggestion has been made to transform international cartels into intergovernmental commodity agreements and include net-importing countries in their operation. This proposal may be worth considering with regard to raw materials industries of exceptional structural maladjustment, provided an entirely novel kind of intergovernmental commodity control is evolved. In the past, such controls were basically as restrictive as international cartels, and cartels have at least the saving feature of being far less stable than government-sponsored restriction schemes.

The second type of remedy proposes to do away with international cartels or with their restrictive policies. The absolute banning of all international business agreements is incomparably the more clear-cut solution. It should be easy to enforce since no formidable problem of definition exists. Yet there seems to be scant belief that so radical a step is practicable on an international scale. The method also has the drawback of outlawing international business agreements which are free of restrictive features. For example, if uncontaminated by restrictive marketing clauses, agreements for the international exchange of technological knowledge or for the establishment of information bureaus appear to be decidedly useful.

An alternative is to forbid restrictive business practices in international trade without banning private'business agreements. Among the restraints singled out for concerted prohibitory action would be arrangements for fixing prices, restricting production or exports, allocating territorial or functional markets, suppressing technology and invention, and boycotting non-cartel members. The full inclusiveness of this catalogue is a matter of detail. This is the core of the program to which the United States has committed itself. The State Depart-

20. Beveridge, Full Euployment in a Free Society (1945) 238.

21. Ibid. 
ment will seek "the concurrence of other countries in an agreement prohibiting the participation of commercial enterprises in contracts and combinations which restrain international trade, restrict access to international markets, or foster monopolistic control in international trade." 22

Beyond this statement of principle, the American campaign against restrictive business practices is exceedingly flexible and far less detailed than, for instance, the proposals on reforming intergovernmental commodity arrangements. Two methods of effectuating the principle have been considered. ${ }^{23}$ One is to lay down, by international treaty, a specific list of international business restrictions which the participating governments would regard as ipso facto violations, and which they would take immediate action to remove, whenever demonstrably pursued. According to the other method, participating governments would regard such practices only as prima facie violations and would talie action only upon complaint of an international agency which would be authorized to recommend but not to enforce such action.

The first method is unquestionably the more forthright, promising far greater speed, certainty, and uniformity of action. The State Department espouses it as a long-range objective but thinls it impracticable for immediate adoption. Aware of the diversity of legal systems, administrative procedures, traditions and interests of different nations, the United States government doubts that many governments would be willing to incorporate uniform definitions of restrictive carte practices and statutory prohibitions in their existing laws. To push such a program at this time, it is felt, would result in a very small common denominator of accord. The State Department, therefore, favors the alternative method which renders certain business practices generally suspect and, upon definite proof that they have inimical effects on the flow of trade in the individual case, would set in motion machinery for remedial action.

Chapters IV and VI of the United States Trade Proposals suggest the establishment by convention of an international code of rules with a view to barring abuses of the power wielded by international cartels. Certain practices will be enumerated and designated as suspect on principle. Difficulties of definition may arise but should not prove insuperable for the intended purposes. A Commission on Business Practices will be set up as a subsidiary of the planned International Trade Organization which, in turn, will be brought into some form of relationship with the institutional structure of the United Nations. ${ }^{24}$ The Commission will be empowered:

22. Clayton, loc. cit. supra note 14.

23. Terrill, supra note 12 , at 158,490 .

24. From Chapters IX and X of the Charter, it appears that such organizations must first be established by intergovernmental agreement and thereafter integrated with the 
(a) to receive complaints from any member (or, with the permission of the member, from commercial enterprises within its jurisdiction who allege that their interests are affected) that the objectives of the Organization are frustrated by a private international combination or agreement;

(b) to inquire into the cartel activities in question and request members to provide information relevant to complaints;

(c) to recommend to the appropriate members remedial action, such as divestiture, reorganization and dissolution, in accordance with their respective laws and procedures;

(d) to request reports from members on their actions in implementing such recommendations; and

(e) to issue reports on its activities.

In addition, the Commission will be authorized to conduct studies and make recommendations concerning uniform standards of fair business practices, the kinds of information which members should file with the Organization, and appropriate intergovernmental arrangements for the international exchange of technological information on a nondiscriminatory basis. Participating governments will have to commit themselves to act upon the recommendations of the International Trade Organization in accordance with their own domestic laws.

Sir Stafford Cripps is right in characterizing this proposal as "a very mild and permissive form of trying to get rid of what has been acknowledged ... as being undesirable. ..."25 Principled opponents of cartelization would wish for something far more rigorous and clear-cut. As outlined, the program is vague on essential points and, if accepted in general, may succeed or fail in its purpose, depending upon the actual degree of agreement and cooperation which can be realized in the course of time. It is quite possible that it is wildly optimistic to expect effective remedies from this kind of consultative and persuasive technique and that the program "offers scope for the maximum of excited complaint and the minimum of prompt action." 26 But it is easy to underestimate the persuasive force of institutionalized complaints and to overestimate the necessity for prompt action. The

United Nations. “. . . [S]pecialized agencies, established by inter-governmental agreement and having wide international responsibilities" in economic, social and related fields (Art. 57, par. 1) may enter into agreements with the Economic and Social Council "defining the terms on which the agency concerned shall be brought into relationship with the United Nations. . . " (Art. 63, par. 1). However, the United Nations "shall, where appropriate, initiate negotiations among the states concerned for the creation of any new specialized agencies required. ..." (Art. 59). In so far as the problem is susceptible to treatment by an international code of rules, apart from an international agency, the Economic and Social Council "may prepare draft conventions for submission to the General Assembly, with respect to matters falling within its competence." (Art. 62, par. 3).

25. 417 H. C. Deb. (5th ser. 1946) 499.

26. The Trade Proposals (1945) 149 The Economist 853. 
American program has, on the other hand, the virtues of its vices. It is pragmatic, tentative and elastic.

At this time, it would be premature to appraise the potential area of international cooperation on this matter. Before the war, western and central Europe were the main breeding ground and domicile of international cartels because they had the capital wealth to invest in the types of industries particularly conducive to cartelization and because, unlike the United States, there was no powerful and formalized "trustbusting" tradition. Since German business will remain under Allied control and will hardly, therefore, be one of the mainstays of international cartelization, much will depend on the attitude of the United Kingdom and France. The state of French politics is in an unpredictable flux at present. Yet there seems to be an unambiguous disposition among the leaders of the Socialist Party and the Popular Republicans to collaborate with the United States in world economic affairs. Great Britain is committed to support the principles of the American program and, despite the Düsseldorf Agreement, cannot be said to be fundamentally pro-cartel. ${ }^{27}$ The ultimate attitude of these two countries will largely depend on the intelligent solution of postwar transition problems and the prospect and success of the United States Trade Proposals. If they decide to support the program wholeheartedly, most other important trading countries can be expected to fall in line. In that event, the American approach toward the cartel problem may facilitate greater progress than seems likely at first sight.

The flexibility of the American program extends in both directions. Resting on a multiple-contingency basis, it provides for an "offensive in depth." According to Chapter IV of the Proposals, members may by mutual accord "cooperate in measures for the purpose of malking more effective any remedial order which has been issued by a duly authorized agency of another member." This clause permits special arrangements among individual members for enforcing anti-cartel measures more severe than the totality of member countries is willing to subscribe to. Such special arrangements may be quite effective. There were not many international cartels that could have been organized or maintained against determined and concerted opposition on the part of even a few important industrial powers. Finally, the Proposals leave any member free to enforce within its own jurisdiction any national statute or decree directed toward the elimination or prevention of restrictive business agreements in international trade.

The United States proposals on international cartels merit approval. Curbing restrictive business practices will not by itself bring about a perfect world trading system. But it can significantly contribute to

27. Lewis, The Status of Cartels in Post-War Europe in EDwands et al., op. cil. stspro note 9 , at $25,28-33$. 
the regeneration of the decaying prewar regime. As a rough blueprint, the American program may be sadly disappointing to the economic purist and utopian to the cynical "realist." But it comes close to the maximum combination of the ideal and the feasible.

\section{Intergovernmental Commodity Agreements}

Both intergovernmental commodity arrangements and international cartels were devised for the purpose of substituting for the anonymous forces of the competitive world market deliberate control over production, marketing, and sometimes prices. Restraint of competition is of the essence of both instruments. The chief difference is that governments assume a more or less decisive role in the one, while the other remains within the province of private enterprise.

Commodity agreements have been set up for a variety of reasons. Some, for instance, were formed to prevent the depletion of exhaustible natural resources (such as the conservation agreements on marine animals: fur seals, halibut, sockeye salmon, whales). Others made arrangements in the interest of public health (e.g., regulation of the trade in narcotic drugs) or had primarily political objectives (e.g., the Anglo-American interim agreement on crude petroleum of 1944). The most important class, however, is represented by agreements on primary commodities which are in chronic oversupply. This is the type dealt with in the United States Trade Proposals.

The problem at issue here is not that of short- or medium-range price oscillations-another curse to primary producers. Such fluctuations arise, on the demand side, from abrupt changes in per-capita incomes and, on the supply side, from unpredictable changes in crop yields. To confine the resulting price gyrations frequently was a secondary aim of prewar commodity arrangements. Their primary objective, however, was to lift a price level depressed by chronic excess supplies, that is, by a fundamental maladjustment of the industry concerned.

As pointed out previously, during the interwar period many important primary industries suffered from chronic conditions of excess supplies, directly affecting millions of small producers and workers and many thousands of managers and investors. Structural maladjustment of the industry was in each case the root cause of the trouble; the world's capacity to produce the commodity exceeded the requirements of the world market. In some fields overexpansion originated in the economic dislocations of World War I (wheat; sugar). Extension of capacity as well as of productivity usually followed technological advances such as improved mining machinery, development of hardier plant varieties, increased use of fertilizers, and better animal breeds and feeding diets. New means of transportation extended the location 
of mineral and agricultural production, and better packing and storage methods permitted a larger proportion of production to reach the final consumer. The gradual replacement of draught animals by motor vehicles set free large areas for cultivating food cereals. The growth of economic nationalism led to the uneconomic extension of production behind protective shelters. Restrictive valorization schemes occasionally stimulated new production under the temporary umbrella of highly attractive prices (coffee, crude rubber). Sometimes, brief periods of short supplies and boom prices resulted in an overcompensated expansion of production.

Temporary maladjustments and unbalances are unavoidable in a world of rapid economic, political and technological change, and in many fields of production, especially in manufacturing industries, the price mechanism of the free market sets forces in motion that tend to reestablish equilibrium without undue delay and distress. When the continued employment of surplus production facilities floods markets and depresses prices, the postponement of further investments and/or actual disinvestment induces a shift of resources into more profitable fields. This process plus the stimulation of increased consumption by low prices tends to readjust production and consumption capacities.

Unfortunately, many primary commodity markets do not conform to this ideal pattern of stimulus and response. The ultimate demand for most industrial raw materials, especially metals, is a joint demand. Its responsiveness to price changes is usually negligible since the value of one raw material (e.g., rubber) in proportion to the value of the entire finished product (e.g., automobile) is exceedingly small. Low prices, therefore, fail to generate an increased volume of demand. The magnitude of consumption is largely determined by fluctuations in real incomes. On the other hand, the specific nature of resources in capital-intensive primary industries (mines, plantations) makes their transfer to alternative employment costly or impossible. Disinvestment is tantamount to painful capital losses and, under the pressure of high fixed costs, production is often maintained as long as prices remain above prime costs. The result is that, except in the very long run, adjustment takes place in price only. The discouragement of new investments and the eventual bankruptcy of relatively inefficient and financially weak enterprises is likely to produce readjustment in the longer run, but the protracted interval is a slow and bitter process of attrition. The markets of basic foodstuffs show roughly the same defects. Rate of consumption is rather insensitive to price changes. Confronted with a sagging price level, farmers of the owner-operator type do not as a rule contract output. Indeed, the price elasticity of supply may become inverse as producers try to maintain a minimum income. Mobility of resources is generally low, particularly in Europe and Asia where farming is not only a business but also a way of life. 
But even in the United States, the total crop acreage did not contract during the Great Depression. In fact, it expanded each year from 1929 to $1932 .{ }^{28}$ Under laissez-faire conditions, therefore, agricultural crises on account of overproduction tend to be severe and prolonged. Surpluses are apt to become chronic.

Faced with such conditions, it is only natural that producers attempt to evade the impasse of the competitive market. Where circumstances are favorable, national and international cartels may be created. Yet this is rarely possible in industries composed of a great multiplicity of independent producers. Their interests, in part divergent, are difficult to reconcile and, should an effective restriction scheme be set up, large advantages are likely to accrue to the outsiders. Organized attempts at voluntary output restriction are invariably abortive. Pleas for government help are the next step. When producers are organized in associations, political pressure re-enforces persuasion. Nor is governmental assistance granted merely for political motives. Governments may genuinely conceive such relief to be necessary in the general interest. Disposition to succor a depressed industry will be in proportion to the numbers of producers and workers involved. Especially in agriculture, the numbers may be large. In industrialized countries with comparatively high-cost farm production, governments are usually unwilling to permit their peasant community to be decimated by foreign competition. In raw materialsproducing countries, frequently dependent on the exports of a few primary products, a persistent depression of prices seriously affects domestic prosperity, balance-of-payments position, fiscal revenues, and, sometimes, political stability. The vast importance of sugar prices to Cuba, tin prices to Bolivia, rubber prices to British Malaya, wool prices to Australia, wheat prices to Canada, and coffee prices to Brazil illustrates the point.

The incentive to help primary producers was strengthened when the cyclical recession of consumption in the early 1930's added to the plight of producers. Most remedies reflected the universal disposition to follow a policy of sauve qui peut. Importing countries-many already committed to agrarian protectionism-reserved their internal markets to their own producers by high tariff walls, import quotas and foreign exchange controls. Many governments granted direct subsidies, debt and tax relief, etc. Exporting countries accorded direct or indirect aid to dumping. By such unilateral action, each government tried to shift the main burden of adjustment to other countries with the over-all result of preserving uneconomic production, disrupting trade channels and, generally, contributing to the disintegration of world trade.

28. Shergerd, Agricultural Price Control (1945) 9. 
It is against this background that prewar commodity agreements must be viewed. They constituted an alternative remedy. Essentially, they were internationally organized attempts at transferring the burden of adjustments from exporting countries to consumers. The restriction schemes on wheat, sugar, tea, tin and rubber are typical of this orientation. Interested countries combined to set up a monopoly or near-monopoly over world market supplies. Government authority insured the enforcement of the plans on individual producers. By export regulation, often reinforced by output control, supply and demand were equated at a price level acceptable to producers. By restricting new supplies, world surplus stoclis were gradually liquidated, and prices rose in response. By maintaining artificially the necessary degree of scarcity, the price level was prevented from declining again. Sometimes control was extended over stocks and new productive capacity, and the 1942 Draft Convention for an international wheat agreement-fairly bristling with restrictions-added the fixing of basic minimum and maximum prices to the duties of the control body.

Like international cartels, these intergovernmental schemes had varied success in terms of their own objectives. In this sense, the International Wheat Agreement of 1931, the Chadbourne Sugar Agreement of 1931, and the International Sugar Agreement of 1937 were failures, while the Tea Regulation Scheme of 1931, the International Tin Control Scheme of 1931, and the International Rubber Regulation Agreement of 1934 were definitely successful from the viewpoint of their sponsors. The former controls collapsed because they did not enjoy a sufficient degree of monopoly power or because not all member countries conformed to the control decisions. They dealt with commodities whose production is spread over the world and can easily be extended by protective devices. To be effective, the interests of too many governments and producers had to be reconciled. By contrast, production of the commodities of the second group is geographically concentrated, relatively few producing countries are involved, and the industries themselves are characterized by a somewhat greater extent of financial integration than are wheat or sugar production.

The general effects of prewar commodity agreements were roughly the same as those of private international cartels that followed comparable methods of output and export control.J Employing restrictive techniques, these intergovernmental schemes tended to raise cost and price levels, to diminish the volume of trade, and to freeze it in existing channels. Provided they did not collapse, they succeeded in securing

29. See KNorr, Tin Under Controd (1945) 214-52; KNors, WorLd Rubber ARD ItS REgULATION (1945) 155-75. 
better incomes to producers at the expense, very largely, of final consumers. In fact, the loss of the latter exceeded the gain to the former. This resulted directly from the fact that these arrangements refrained from attacking the root cause of the trouble. Instead of eliminating extramarginal producers more speedily and less painfully than the competitive process was apt to do, these controls preserved excess capacity and protected the value of malinvestments. In principle, output restriction was applied on the basis of arithmetic equality to efficient and inefficient producers alike. The structure of the industries was not readapted to average market requirements, allowing for reasonable reserve capacity. Continued prosperity, therefore, was left to rest on the perpetuation of international restriction. To shift the costs of this superficial remedy to the importing countries and consumers, to subordinate considerations of general welfare to the special interests of limited groups, did not prove difficult since these arrangements were created and operated by producing interests and exporting countries. The mere involvement of governments did not make these controls essentially different from private cartels.

This analysis cannot be invalidated by references to tenuous instances of consumer representation, to the fact that quota agreements can adjust supplies upwards as well as downwards, or to the alleged attempt of control bodies to manipulate no more than a "fair" price for the commodity. The rubber and tin schemes provided for a few consumer representatives. But they represented solely the interests of industrial consumers; they enjoyed only advisory rights, and they had no dependable influence over control policy. Undoubtedly, control authorities adjusted the flow of supplies to changing market requirements, and they increased supplies when requirements expanded. But they equated supply and demand at a price which in the long run was higher than would have evolved in a free market after amputation of surplus production facilities. ${ }^{30}$ Too often they did not increase supplies fast enough in a rising market. The "controllers" had to engage in the speculative business of forecasting demand volumes many months ahead and, obviously, they tried to minimize the risk of fixing an excessive rate of supply by underestimating rather than overestimating future requirements.

Under conditions of control, the notion of a "fair" price involves arbitrary assumptions. It cannot be reduced to precise criteria. Ultimately, the price level actually manipulated represents a political price arrived at through bargaining between different producing interests and influenced by a variety of considerations such as the actual or potential menace of outside rivals and the desire to avoid international

30. Mason, The Future of Commodity Agreements in SchuLTZ (ed.), FOOD FOR THE WORLD (1945) 230. 
ill-will. ${ }^{31}$ But the institutional ability to rig prices to a very high level represents a perennial temptation not alway's easy to resist. The International Tin Committee, for example, exhibited far less moderation than the Rubber Committee. If the International Tea Agreement has a comparatively excellent record, this was the result of the participating countries representing at the same time the chief producing and consuming interests. ${ }^{32}$ However, to call the supply policy of the Tea Committee moderate is not to say that the scheme was bare of the restrictive features and effects objectionable on general grounds. Nor can the Draft Convention for a future international wheat agreement escape this basic criticism. Formulated in 1942 and widely publicized as a sort of model for postwar control schemes, it is studded with restrictive measures. ${ }^{33}$

It is clear that prewar intergovernmental commodity agreements were not a desirable form of international economic cooperation. They ran counter to the rule that a remedy must not, in its general effects, be worse than the evil it is supposed to mitigate. They violated the overriding principle that interference with the free market must not substantially hinder the rise of world real income. The contention that, as compared with cartels, the participation of governments introduces interests broader than those of solely producer-orientated controls is not supported by the record. There are those who make a virtue of this fact and those who find excuses for it. Some candidly defend these agreements as government-supported monopolistic controls intended to force an equitable redistribution of income in favor of the farmer and to secure for the unorganized primary producer some of the monopoly gains hitherto pocketed by industrial producers and organized labor. Others find excuses in the underlying conditions of the interwar period when world economic collaboration was at such a low ebb that a constructive international solution was impracticable and nearly every country pursued a beggar-my-neighbor policy.

Admittedly, primary producers and countries exporting raw materials nursed legitimate grievances. They had a righ to demand relief from a problem which was international in scope. Not only were many individual industries and countries affected immediately, they also became sources of economic maladjustment from which disturbing tendencies spread to the world economic structure. The problem was international; so had to be its solution. At best, national self-help could in some countries ameliorate the crisis, albeit at considerable social costs. Intergovernmental restriction schemes were no more than

31. Over the short term, of course, prices were infuenced by errors of control policy and remained susceptible to general cyclical forces.

32. See WiCKIZER, TEA UNDER INTERNATIONAL REgulation (1944) 110.

33. See Davis, Nero International Wheat Agreements (19:2) 19 Whest Studes of TIID Food Research Institute, Stanford University 25, 42 el seq. 
a form of coordinated self-help among exporting countries. They were approved by the international conferences of the 1930's ${ }^{34}$ because no better solution was feasible in a disorganized world. Will there be a better one in the future?

The future complexion of the problem of chronic surpluses will be determined largely by the general political, economic and institutional environment of the postwar world. Should trade barriers be substantially reduced, discriminatory practices abolished, and a high degree of international monetary stability achieved, one perennial cause of surplus output capacity would be automatically obviated. The duplication of productive facilities as a result of protective devices would decrease. Should the key industrial countries succeed in confining the fluctuations of the business cycle within relatively narrow bounds, raw commodity prices should be far more stable than before and average absorption should greatly expand. The establishment of international study groups for the most important primary products should facilitate constant consultation among governments and permit the systematic gathering, interpretation and dissemination of facts relevant to industries and markets. Consultation and precise information can do much to prevent overinvestment and the temporary shortages which, through high prices, are apt to promote overexpansion.

The problem of chronic surpluses would not disappear under such conditions. It would find less widespread expression, and, in an expansive environment, the shift of resources from overexpanded to expandable industries would be facilitated. But the quest for specific remedies would be renewed whenever an important primary industry found itself confronted with chronic surpluses. Such situations are likely to be particularly numerous during the postwar transition period. Just as after the first World War, many industries will be overexpanded in relation to normal peacetime requirements. What action should be contemplated to meet this problem?

There are those devotees to international planning who advocate the prewar type of commodity agreement in preference to leaving critical industries exposed to the competitive market. But the choice need not be limited to the two alternatives. The goal is an instrument of economic adaptation superior to both. Recognizing that restriction schemes injure consumers' interests, some planners propose to reform these controls by according equal authority over them to importing and exporting countries. But even if this arrangement should protect consumers against extreme abuse of monopoly power, it would do nothing to alter the restrictive nature of the device. As before, intergovernmental commodity agreements would preserve excess capacity,

34. League of Nations, Raw-Material Problems and Policies (1946) 76-7. 
protect high-cost producers, obstruct economic progress and diminish trade.

To be constructive and in keeping with an expansive world economy, planning must extend to the crux of the problem. It must center on the removal of surplus productive capacity-the locus of maladjustment. The job is not to prevent change, to resist the corrective forces of the competitive market, and to ban the shifting of unemployed resources to more remunerative fields of employment. The problem is to make the needed changes proceed smoothly and to speed up capacity contraction and resource transfer without exposing the entire industry to protracted income depression. To be practicable, on the other hand, planning must not shun compromise. There is no sense in projecting a quick surgical operation to which the patients cannot be made to submit. Some restriction will be the inevitable part of regulation acceptable to diverse interests. The important thing is to subordinate such restriction to the ultimately expansive endeavor and to keep it at a minimum in extent and time.

It is not too difficult to set down the principles of an adequate program. (1) To permit of truly international remedies, a code of rules and procedure must be formulated and machinery provided for its application. (2) Action should commence preferably before the surplus situation has become critical. (3) Increased consumption must form the first line of attack. (4) If absorption remains insufficient, the inflated industry must be readapted to world consumption capacity in an orderly manner. (5) Such readjustment should comprise the disinvestment of redundant and sub-marginal producing units and allow structural changes in the direction of economic resource utilization. (6) If output and export regulation is indispensable to orderly readjustment, such restrictive control must be confined to important primary industries; it must be strictly limited in time, and it must afford ample protection of consumers' interests.

This is indeed the general approach of the United States Trade Proposals. Members of the projected International Trade Organization are urged to adopt the following procedure. Member countries principally interested in the production or consumption of a raw commodity, of which excess supplies exist or are threatened, will undertake a special study with the view to expanding consumption.

"If it is concluded, in the light of an investigation of the root causes of the problem, that measures for increasing the consumption of a commodity are unlikely to operate quickly enough to prevent excess supplies of the commodity from accumulating, the members may ask the Organization to convene an intergovernmental conference for the purpose of framing an intergovernmental commodity agreement for the commodity concerned." 35

35. U. S. Trade Proposals 20. 
Three principles are to govern the institutions of such agreements. First, consuming as well as producing countries "should be entitled to participate in the consideration of the proposed agreement." 36 Secondly, arrangements involving the limitation of production or exports or the allocation of markets should not be undertaken unless

(a) "a burdensome surplus of the product concerned has developed or is developing in international trade and is accompanied by widespread distress to small producers accounting for a substantial proportion of the total output and that these conditions cannot be corrected by the normal play of competitive forces because, in the case of the product concerned, a substantial reduction of price leads neither to a significant increase in consumption nor to a significant decrease in production . . . ;"37 or

(b) "widespread unemployment, unrelated to general business conditions, has developed or is developing in respect of the industry concerned and that such unemployment cannot be corrected by the normal play of competitive forces rapidly enough to prevent widespread and undue hardship to workers because, in the case of the industry concerned, i) a substantial reduction of price does not lead to a significant increase in consumption but leads, instead, to the reduction of employment, and ii) the resulting unemployment cannot be remedied by normal processes of reallocation. ..." 38

The former case obviously refers to agricultural industries of the owner-operator type, the latter mostly to large-scale mineral industries. In either case, such controls are to be applied only when "the need is real and serious, affecting many people. . .." ${ }^{39}$ Thirdly, members must formulate and adopt a program of economic adjustment believed adequate to insure substantial progress toward removing "the root causes of the problem." 40

Restrictive control, then, is "to provide a period of transition which will afford opportunities for the orderly solution of particular commodity problems by agreement ... upon a program of over-all economic adjustments designed to promote a shift of resources and manpower out of over-expanded industries into new and productive occupations." " ${ }^{11}$ The purpose is not to protect vested interests but to effect change along an orderly pattern. For this reason, controls "should be strictly temporary, lasting no longer than required to carry

36. Id. at 21 .

37. Ibid.

38. Ibid.

39. Id. at 6 .

40. Id. at 20 .

41. Id. at 21 . 
out the necessary shifts." 12 Initially, agreements should not remain in effect for more than five years, renewal being subject to certain definite rules. For their protection, consuming countries are to have a voice in the regulation of prices, trade, stocks, or production, "equal to those largely interested in obtaining export markets for their production." " 43 Furthermore, there must be "provisions for assuring the availability of supplies adequate at all times for world consumption requirements at reasonable prices." 44

Compared with prewar commodity agreements, this plan appears felicitous in conception. One commentator indeed speaks of the "almost clinical purity" of its approach."5 However, it is clear that these proposals are barely more than general statements of principle. It is perhaps overly pragmatic to believe that "the proof of any principle is in its application," 46 but the record of international economic cooperation is replete with instances of disregard and violation in practice of agreed principles. One trouble is that the principles in question are capable of widely varying interpretation, another that their application becomes difficult in direct proportion to the rigor with which they are interpreted. These dangers can be easily exemplified by referring to the problems of (1) recognizing the necessity of concerted intervention in a commodity market; (2) planning expanded consumption; (3) formulating adequate readjustment plans; (4) limiting the duration of restrictive controls; and (5) affording sufficient protection to consumers' interests.

(1) Necessity of concerted intervention. As stated previously, the number of intergovernmental commodity arrangements should be kept to a minimum because of their unavoidably restrictive effects. It is intended to confine such schemes predominantly to basic foodstuffs and raw materials, their application to fabricated products being limited to "exceptional circumstances." 47 International investigation and consultation are to start when excess supplies prevail or are threatened. No criteria are offered for recognizing the existence of such conditions. This is indeed impracticable since different commodity markets have peculiar characteristics. In some markets, the accumulation of visible supplies may furnish ample evidence, but in general it is prices in relation to cost trends which must be taken as the starting

42. Id. at 6.

43. Id. at 22 .

44. Toid.

45. The Trade Proposals, supra note 26 , at 854 .

16. U. S. TRAde Proposals 3.

47. The pressure for intergovernmental restriction on manufactures will obviously be great if the restrictive practices of private international business agreements are effectively curbed. 
point, for a surplus situation may exist, expressed in very low prices, in the absence of excess visible stocks.

Intergovernmental control agreements are planned only if burdensome commodity surpluses lead to widespread distress to small producers or to widespread unemployment unrelated to general business conditions and if in either case the normal play of competitive forces fails to rectify the situation within a reasonable period of time. Both price responsiveness of consumption and resistance to disinvestment and resource shift are capable of fairly precise measurement. Difficulties will arise in diagnosing the "wide spread" of distress and unemployment. What if these phenomena are exhibited, because of high costs or the specific nature of the product, predominantly in one important producing country or only in a number of smaller ones? What if these phenomena are not engendered in some countries because of domestic price-support programs? What if, in mining industries, a surplus situation finds its expression in declining wages rather than in largescale unemployment which is more likely to develop where wage costs are incapable of compression? It seems reasonable to assume that the planners will focus their attention on net-exporting countries and will consider introducing a readjustment and restriction scheme only if the signs of distress are visible in those major countries of this category which do not subsidize their exporters or producers.

Yet inevitably a great deal of discretion will be left to the investigating and planning body, and much will therefore depend upon their wisdom, authority, and good will. This impression is reinforced if the problem of timing is considered. The earlier an emerging industrial malady is diagnosed and treated, the easier it is to create relief by expanding consumption and to remedy basic maladjustments. Such laudable preoccupation, however, encompasses the danger that once the machinery is set in motion it cannot be stopped before it has run its full course; the danger, in other words, is that there will be too many réstrictive agreements. The problem of timing extends to the effects of cyclical market disturbances. When general business conditions are brisk, the fact of redundant production capacity may not be fully appreciated since it is believed that with a little additional increase of consumption it will disappear. Nothing will be done. When business contracts, the problem of surplus capacity is overlaid by that of cyclical oversupply, and the trouble assumes formidable dimensions. ${ }^{49}$ Corrective planning, moreover, is greatly facilitated when undertaken in times of general business expansion.

(2) Planning expanded consumption. It is an excellent idea that expansive measures should precede restrictive ones in mitigating a surplus situation. New uses as well as éstablished outlets should be

48. League of Nations, op. cit. supta note 34 , at 80 . 
canvassed for possible consumption increases. In wealthy countries, absorption may be expandable in processed form (e.g., wheat used for feed). Importing countries may be persuaded to slash revenue taxes (e.g., on coffee). Most important perhaps is the diffusion of abundance to economically less developed and poverty-stricken areas. Two-price systems or special joint loans might well be considered in order to supply countries without adequate purchasing power to satisfy their needs at world market prices. ${ }^{49}$ The International Tea Committee, for example, stimulated a doubling of Indian tea consumption by advertising and the fixing of an Indian tea price substantially below the world market price. Complex problems will doubtless be met in applying such ideas on a broad scale. Thus far, there is no agreed body of doctrine on how to apply them in international concert. The problem is to combine all the ingenuity displayed in national subsidy and international restriction programs and put it behind a constructive purpose.

(3) Formulating readjustment plans. Restrictive commodity agreements are bad. The essence of restoring health to an industry depressed on account of surplus productive facilities is to readjust its structure. To make the adjustment proceed in an orderly fashion, without plunging the entire industry into prolonged distress, is the sole constructive purpose of temporary suspension of the free market. The desirability of the scheme proposed by the United States stands or falls with the implementation of effective plans of industrial readaptation. This is the heart of the program and its most difficult part. Not all producers can survive. Where excess capacity is the root of the trouble, it cannot be left intact. It must be amputated and, as the Proposals insist, such capacity contraction should follow economic lines by eliminating submarginal producers from the industry.

The formulation of an effective plan is vastly complicated by the fact that inefficient producing units are not equally distributed among the various producing countries. Sometimes, as in the case of tin (Bolivia) or sugar (the beet sugar countries), a country's industry as a whole may be distinctly high-cost. To proceed economically, therefore, unequal degrees of painful adjustment must be expected from different countries. Since the agreement and consent of these countries is essential to a concerted plan, it is clear that there must be at least a partial sharing of such unequal burdens. International cooperation, help, and compensation is needed especially where the industry concerned forms an important portion of the entire economy.

Provided the demand for the commodity concerned exhibits secular growth and capacity redundancy is not extreme, adjustment can be achieved by a gradual dismantling or lowering of producer subsidies

49. Feis, The Sinews of Peace (1944) 247. 
in all forms. Agreements to abandon export bounties and perhaps preferential tariff arrangements and import-quota protection, to reduce tariffs, and to limit or discontinue price-support programs-all indicating the presence of inefficient production-may be sufficient to bring an industry back to health. ${ }^{50}$ Other industries will call for a more radical plan of selective retrenchment covering large segments in exporting countries to whose economy the industry is of vital concern. This involves particular difficulties in economically less advanced countries. The active facilitation of resource transfer on a large scale is an obvious prerequisite. The state of other industries must be considered. Financial and technical assistance must be forthcoming, workers must be resettled and retrained, farmers reequipped, and industrialization promoted. Such project need not only be mapped out but also must be financed in cooperation.

To state the problems is to state the complexity and dimension of the task. In nearly every individual case, capacity contraction may appear to conflict with other aims of economic policy such as fullemployment programs or attempts at reducing dependence on foreign supplies. Farmers and laborers are prone to resent and resist their shift to other occupations. Investors will do their utmost to prevent capital losses. Enforcement will be troublesome wherever a multitude of producers is involved. Other problems will be posed by export, output and, possibly, price control. To provide an additional incentive toward optimum adjustment and, generally, to "make appropriate provision to afford increasing opportunities for satisfying world requirements from sources from which such requirements can be supplied most effectively." ${ }^{51}$ Equalitarian restriction, as practised by prewar schemes, must give way to non-equalitarian restriction becoming increasingly severe on high-cost and easier on low-cost sources of supply. Prices must remain relatively low in order to encourage the growth of consumption and limit inter-commodity competition.

(4) Duration of restrictive controls. Under the United States Proposals, intergovernmental commodity agreements are conceived as transitional expedients. Hence the emphasis that, when set up, controls of this sort "should be strictly temporary, lasting no longer than required to carry out the necessary shifts." ${ }^{2}$ The length of the period depends, of course, on the magnitude of basic maladjustment and will be affected by the peculiarities of different industries. It must be neither too short nor too long. If it is too brief, the lasting success of the readjustment plan may be jeopardized; if too long, restriction

50. See Haley, United States Policy Regarding Commodity Agreements (1945) 12 Dep'T of State Bull. 638, 642.

51. U. S. Trade Proposals 22.

52. Id.at 6. 
ceases to fulfill a useful function. To set the right length will require the most judicious appraisal.

According to the Proposals, agreements are not to remain initially in force for more than five years. Renewal should be subject to the principles governing the formation of new agreements (the existence of a distress situation as defined) and to the additional rule that "either substantial progress toward a solution of the underlying problem shall have been accomplished during the initial period of the agreement or that the renewed agreement is so revised as to be effective for this purpose." 53 The wording of the last clause is apt to arouse serious doubt and suspicion. Instead of furnishing an additional incentive toward the speedy reorganization of a depressed industry by setting a definite time limit on the duration of transitional restriction, it seems to do the opposite. A readjustment scheme must, of course, be elaborated-on paper. But if it is not executed, in which case the abandonment of control would automatically precipitate the distress situation that necessitated an agreement in the first place, restrictive control can be renewed by simply elaborating a revised adjustment schemeon paper. This provision, therefore, invites procrastination on the primary purpose of intergovernmental control. Unless revised, it must be regarded as an escape clause permitting the indefinite perpetuation of restriction while defeating constructive change. The danger that removal of "temporary" restriction is indefinitely postponed must be forestalled. Analogous cases of protective devices intended to be temporary but hardly ever lifted; such as emergency and infant-industry tariffs, demonstrate how real the danger is. ${ }^{54}$

(5) Protecting consumer interests. Contrary to prewar agreements, the new arrangements provide for full participation of countries chiefly or solely interested as importers and consumers of the commodity concerned. They are to have a voice, equal to exporting countries, in the formation and administration of controls. Commodity agreements, furthermore, are to be so operated as to make available at all times and at "reasonable prices" supplies adequate to satisfy world consumption requirements and to allow for a progressively larger flow of supplies from low-cost sources of supply. Provisions for the periodical review of, and for full publicity on, the operation of the agreements may also be regarded as safeguards of the consumers' interest.

Nevertheless, the issue of consumers' protection presents both practical and theoretical difficulties. There is the practical problem of avoiding deadlocks in administering controls when importing and exporting countries possess equal power. ${ }^{55}$ There is the problem of

53. Id. at 22 .

51. League of Nations, op. cit. supra note 34, at 79.

55. FEIS, op. cit. supra note 49 , at 245. 
who should bear the risk of faulty control decisions resulting in ill effects on producers and exforting nations. There is the problem of defendably assuring the availability of adequate supplies at all times, a condition which in most cases can be satisfied only by the creation of ample reserve stocks. There is, finally, the fundamental problem of how to protect the ultimate consumer in a world in which he alone of all interested parties is unorganized and therefore incapable of making his weight felt in the political process.

One thing is clear. The interest of the industrial consumer and processor-largely determined by the financial risks of holding working stocks-does not coincide with that of the final consumers. ${ }^{\text {ig }}$ Unorganized, the latter cannot be represented by their own delegates. Representation by government is the only feasible alternative. However, for the greater number of foodstuffs and industrial materials, most importing countries are also producing countries and they are high-cost producing countries wherever protection is accorded in one form or other, which is the rule rather than the exception. By necessity, their governments represent the interests of both their home producers, usually organized, and their consumers, usually unorganized. Be the interest of the latter ever so much greater than that of the former, governments in response to pressure tend to favor the organized as against the unorganized group. ${ }^{57}$ Despite equal representation of importing and exporting countries in control schemes, the prospects are that producers' interests will on balance be more strongly represented than consumers' interests.

These five problems discussed above are examples of the difficulties to be met in the actual establishment and administration of intergovernmental commodity agreements. They could easily be multiplied. But they suffice to indicate that the proposal and acceptance of excellent general principles is only a first step. The real task lies in their application. It would be misleading to hold out the hope that the spirit of the Proposals is bound to come to fruition. Most important trading countries have favored commodity agreements of the exclusively restrictive prewar type. To name Great Britain, the Netherlands, Belgium, France, Canada, Australia, Argentina and Brazil is only to mention the more important ones. Yet the most ominous fact is the record of the United States itself. There is in the American record no principled and consistent opposition to governmental restriction schemes as there is to private cartels. To be sure, it would be in the enlightened interest of the United States to lead the fight against restriction for, on balance, the country is a net-importer of primary

56. See KNORR, Wordd Rubber and Its Regulation 173-5; KNORR, TIN UNder CONTROL 244-7.

57. See Fisher, Economic Progress and Social Security (1945) 285. 
products. Admittedly, the United States has looked askance at the schemes for rubber and tin, commodities of which it was not a producer. Also, the drafting of the Proposals here discussed is evidence of clear thinking among government planners.

But there are counteracting factors. The United States has favored restrictive agreements on wheat of which it is a producer. It was the primary driving force in framing the 1942 Draft Convention for an international wheat agreement which would hardly fit the pattern of the Proposals. Similarly, the pressure and aspirations of the cotton and wool interests make it doubtful that the country's attitude toward cotton and wool schemes would be in keeping with the guiding principles of the Proposals. It is equally doubtful that the United States would make an "expansive" contribution toward the solution of the world sugar problem. The unpalatable fact is that United States practice regarding tariffs, export bounties, and domestic price-support programs for agricultural products is out of line with the object of adaptive rather than restrictive commodity agreements. Such incompatibility of orientation is reflected in the varying attitude taken among different government departments toward commodity agreements. The Department of Agriculture, for example, labors too much under the preoccupation with surplus farm products to permit itself the interest in overall principles displayed by the Department of State. Congressional leanings can be easily imagined. This country cannot, on the one hand, insist on purity of approach toward commodities in which it is interested only as an importer and, on the other hand, show zest in compromising with evil when its interests as a high-cost producing country are at stake. The danger is that it will unify its policy by adopting restrictionism all around.

There are three salient reasons, then, why the curbing of restrictive policies of international cartels is more likely to enjoy success than the framing of intelligent commodity agreements. First, the American attitude is as ambivalent toward governmental commodity schemes as it is strongly and unambiguously anti-cartel. Second, primary industries composed of numerous producers and hence unsuitable to private cartelization will be able, in this phase of history, to exert far more political pressure than industries composed of a handful of large concerns. And they will press for painless relief through price-support programs pure and simple and resist change if it hurts. Third, banning a few clearly definable business practices in mass-production industries is infinitely less complex than reorganizing entire industries involving thousands or millions of producers and many countries. The former task is relatively simple and of a type most governments are adept to perform. The latter requires sophisticated perception of multitudinous facts, political wisdom and incorruptibility of principle-all to a degree uncommon among modern governments. 
There is no cause for defeatism. No policy is incapable of change, but it is well to realize that change is often slow. To see the obstacles in the way of intelligent commodity agreements is a step in the right direction. It shows the need for widespread diffusion of information and public guidance as well as for the right kind of government planning.

To sum up: the United States proposals on international cartels look disappointing at first sight but gain respect on further consideration. The proposals on intergovernmental commodity agreements appear excellent in theory, but it is difficult to visualize these principles translated into practice. 